\title{
ANALYSIS OF FRACTAL CHARACTERISTIC OF FRAGMENTS FROM ROCK BURST TESTS UNDER DIFFERENT LOADING RATES
}

\author{
Bao-zhu Tian, Shan-jun Liu, Yan-bo Zhang, Zhan-le Wang
}

Original scientific pape Rock burst is a common serious geological hazard in underground engineering, which seriously affects the progress of projects. The mechanism of rock burst can be explained by the distribution law of rock fragments and its fractal characteristics. A simulation experiment of rock burst was conducted with the granite samples under a biaxial loading machine system to analyze the fractal characteristics of the fragments from rock burst tests. The granite fragments were collected and divided into coarse, medium, fine, and micro grains by a screening method. The number and mass distribution of the fragments in different size ranges were also analyzed. The fractal dimensions of the rock fragments were calculated by the mass-granularity distribution method. Results show that the loading rate is proportional to the damage degree of rock burst; the mass of rock burst debris increases with the increase in loading rate, which indicates that a high loading rate leads to considerable rock damage. A high loading rate also results in small proportions of fine and medium grains and a large proportion of coarse grain, with no significant change in the micro grain. Under the high-loading-rate condition, the fractal dimensions of rock fragments are small, but the released energy of rock burst is large. The conclusions obtained in this study confirm the feasibility of reducing the risk of rock burst by adjusting the excavation rate in engineering practice and provide the basis for further study on the mechanism of rock burst.

Keywords: fractal dimension; fragments; loading rate; rock burst; rock mechanics

\section{Analiza fraktalnih karakteristika krhotina kod ispitivanja rasprsnuća stijene pri različitim stupnjevima opterećenja}

Izvorni znanstveni članak

Prsnuće stijene je uobičajena ozbiljna geološka opasnost kod podzemnih tehničkih radova koja uvelike utječe na razvoj projekata. Mehanizam prsnuća stijene može se objasniti zakonom raspodjele komadića stijene i njihovim fraktalnim karakteristikama. Proveden je simulacijski eksperiment rasprsnuća stijene s uzorcima granita pri dvoosnom opterećenju strojnog sustava u analizi fraktalnih karakteristika krhotina rasprsnule stijene. Krhotine granita su sakupljene i metodom selekcije podijeljene u grube, srednje, fine i mikro zrnca. Broj i raspodjela mase krhotina po veličini u različite nizove također su analizirani. Izračunate su fraktalne dimenzije krhotina stijene metodom distribucije mase-zrnatosti. Rezultati pokazuju da je stupanj opterećenja proporcionalan stupnju štete nastale prskanjem stijene; masa ostataka stijene povećava se porastom stupnja opterećenja, što pokazuje da visoki stupanj opterećenja dovodi do znatnog oštećenja stijene. Visoki stupanj opterećenja također rezultira malim količinama finih i srednjih zrna i velikim iznosom grubih zrna, uz zanemarivu promjenu mikro zrna. U uvjetima visokog stupnja opterećenja, fraktalne dimenzije ostataka stijene su male, ali je oslobođena energija rasprsnuća stijene velika. Zaključci dobiveni ovim istraživanjem potvrđuju mogućnost smanjenja rizika rasprsnuća stijene podešavanjem brzine iskapanja kod tehničkih radova i osnova su za daljnja istraživanja mehanizma rasprsnuća stijene.

Ključne riječi: fraktalna dimenzija; krhotine; mehanika stijena; rasprsnuće stijene; stupanj opterećenja

\section{Introduction}

During underground engineering and construction in a high-stress environment, the initial underground stress, geological structure, and human factors combined with other factors can lead to stress redistribution of the excavation-affected areas. The stress concentration reaching a certain extent leads to rock burst. Rock burst enables the formation of varying degrees of rock fragments and can cause significant harm to the staff and construction equipment [1]. The distribution and ejection speed of rock fragments directly reflect the damage degree of underground engineering.

Researchers have used different theories to analyze the mechanism of rock burst, including stiffness theory, energy theory and catastrophe theory to control rock burst [2-4]. The fragments generated in rock burst are closely related to the stress condition, lithologic structure, and energy consumption of rock burst. Therefore, several scholars have proposed that the analysis of the fragmentation characteristics and the broken extent of fragments can provide basic data for the mechanism of rock burst. He et al. reported that rock burst fragments have obvious characteristics of sheet and block, whereas most rock debris have irregular pyramid shapes under uniaxial and triaxial compressive stresses [5]. Liu et al. proposed that the crushing degree of impact rock burst fragments is high, accompanied with observably blocky characteristics [6]. Nie determined that the length-towidth ratio of sandstone fragments is approximately 1.5 , and the sandstone fragments of strain rock burst mostly have a rectangular shape [7]. Zhao considered that the fragments generated from rock burst mainly exhibit a platy structure, and the proportion of fragments with a blocky structure having a large length-to-thickness ratio is large when the unloading rate is high [8].

Many scholars have used the fractal method to analyze the fragmentation degree of rock mass under the action of external force, and the released energy of the destructive process is extensively investigated. Xie et al. analyzed the fractal characteristics of rock fragments by fractal technology. A certain rule exists between the degree of rock fragmentation and the energy absorbed by unit volume rock. When the rock is destroyed, the energy absorbed by the unit volume rock and the degree of rock fragmentation are high. Therefore, from the energy viewpoint, the deformation and failure of rock can be better described [9]. Shivakumar et al. reported that the rock burst debris exhibit self-similarity by analyzing the characteristic of the rock particle size [10]. Kruhl presented newly developed fractal geometry methods and discussed the correlations between structure quantifications and the rock structure-forming processes [11]. The research of Nagahama showed that the 
relationship between damage and energy dissipation of rock is nonlinear under the small-sized specimens of uniaxial testing by using fractal theory [12]. Huang et al. observed that the characteristics of the fragment fractal of fractured marble specimens are locally obvious under an unloading confining pressure with triaxial high stress and only in a certain range of sizes, which is smaller than a certain feature scale (the threshold of fractal feature sizes), and present a good fractal property [13]. James et al. determined that the fractal dimensions of the cumulative distribution of fragment sizes are approximately 2 , indicating that comminution is a dominant fragmentation mechanism in the dynamic fragmentation of granite tests [14]. Feng et al. considered that the energy distribution of microseismic events during the development of immediate rock burst has a fractal structure. The fractal behaviour of microseismic energy during the development of immediate strain burst and immediate strain-structure slip rock bursts is distinguishable [15]. He et al. conducted true triaxle loading and unloading tests of rock specimens and analyzed the fractal characteristics of rock debris under different loading and unloading paths; these loading paths are more in line with the stress process of the actual engineering rock mass [16]. Li et al. deduced that the fractal dimension for either crack or fragment exhibits a decreasing trend with the decrease in unloading rate in the true triaxial rock burst experiments with four different unloading rates, indicating a reduction in the damage level [17].

Reducing the mining rate is an important measure to prevent and control rock burst in actual projects, for that an increase in exploitation will inevitably lead to an increase in the stress of the surrounding rock mass in unit time. An increase in the loading rate of surrounding rock will influence the stress transfer process, and the deformation and stress distribution of surrounding rock are affected, thus the failure modes of rock mass are closely related to the loading rate $[18,19]$. Therefore, the fractal characteristics of rock burst fragments under different loading rates should be analyzed.

This study selected granite as the experimental object to conduct a simulation experiment of rock burst under different loading rates to obtain the distribution of rock

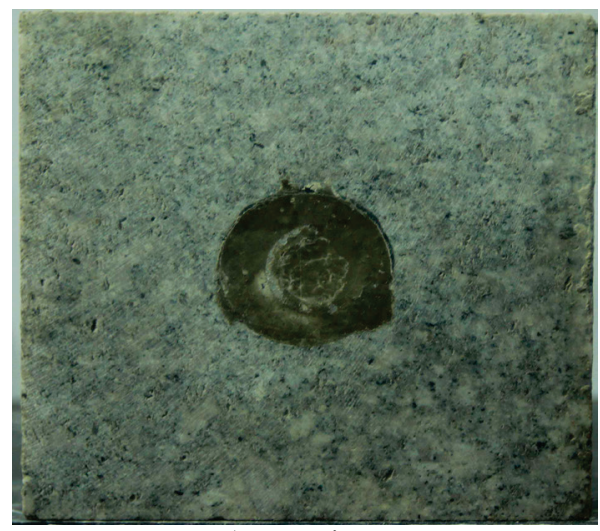

a) Front view burst fragments under different test conditions. From the self-similarity of fragmentation and the energy dissipation of rock burst, the fractal characteristics of rock burst fragments under each loading path were analyzed. The finding can provide the basis for further study on the mechanism of rock burst and is significant for the safety of underground engineering and construction.

The remainder of this paper is organized as follows: Section 2 introduces the rock samples and experimental schemes used in the rock burst simulation experiment under different loading rates. Section 3 analyzes the macroscopic failure phenomena of rock burst simulation experiments and the particle size distribution characteristics of rock burst debris at different loading rates. Section 4 calculates the fractal dimension of rock debris and analyzes the relationship between fractal feature and energy release of rock burst. Section 5 concludes the study.

\section{Materials and methods \\ 2.1 Test samples}

In the experiment, the granite specimens were processed into a cube with sizes of $150 \mathrm{~mm} \times 150 \mathrm{~mm} \times$ $150 \mathrm{~mm}$ (length $\times$ width $\times$ height) in accordance with the international rock mechanics test specification (Fig. 1). Whether the Engineering Rock Mass produces an unloading effect depends on the excavation of rock burst. So the experiment simulates excavation of granite specimen roadways. Because of the high strength of granite, simulating the excavation process in laboratory is more difficult. Therefore, a filling cylinder is preembedded in the same shape of the cave in a pre-specified location, and when it comes to the experimental condition, the cylinder is pulled, forming the roadways once for all. Then the excavation simulation mode is successfully made. Given that the influence range was three times to five times that of the roadways radius after excavation, a hole with $45 \mathrm{~mm}$ diameter was drilled in the middle of each sample and filled by mixing expansive cement, quartz sand, and water-reducing agent, such as a combination of materials. Experimental samples were maintained for three days to increase the strength as close to the granite.

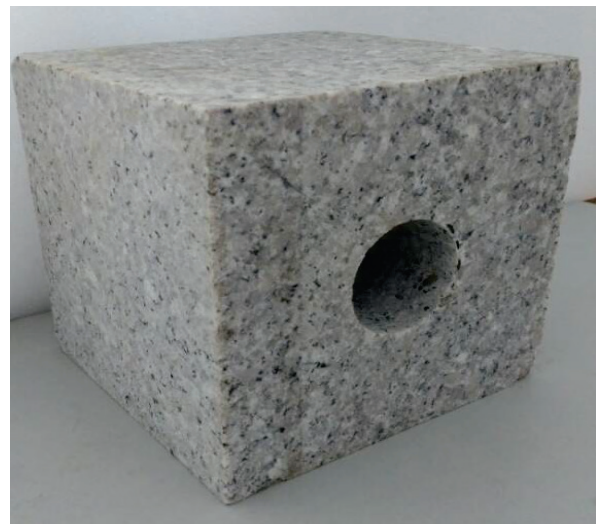

b) Lateral view

Figure 1 Granite sample with a hole

One of the necessary conditions for the occurrence of rock burst is that the rock itself has the property of storing substantial elastic energy. Therefore, the energy criterion method was selected for calculating rock burst tendency. 
The formula for evaluating rock burst tendency is expressed as follows:

$$
U=\frac{\sigma_{c}^{2}}{2 E},
$$

where $\sigma_{\mathrm{c}}$ is the uniaxial compressive strength and $E$ is the elastic modulus of rock. $U$ indicates the rock burst tendency. When the strength limit is reached under the condition of uniaxial compression, rock burst can be divided into four grades according to the elastic strain energy stored in the rock, as follows: $U<40 \mathrm{~kJ} / \mathrm{m}^{3}$, rock burst is level I (indicates no rock burst); $40 \mathrm{~kJ} / \mathrm{m}^{3}<U \leq$ $100 \mathrm{~kJ} / \mathrm{m}^{3}$, rock burst is level II (indicates moderate rock burst); $100 \mathrm{~kJ} / \mathrm{m}^{3}<U \leq 200 \mathrm{~kJ} / \mathrm{m}^{3}$, rock burst is level III (indicates strong rock burst); and $U \geq 200 \mathrm{~kJ} / \mathrm{m}^{3}$, rock burst is level IV (indicates violent rock burst). The granite samples measured by this method are shown in Tab. 1 .

Table 1 Test results of rock burst tendency
\begin{tabular}{|c|c|c|c|c|}
\hline No. & $E(\mathrm{GPa})$ & $\sigma_{\mathrm{c}}(\mathrm{MPa})$ & $U\left(\mathrm{~kJ} / \mathrm{m}^{3}\right)$ & $\begin{array}{c}\text { Rock burst } \\
\text { level }\end{array}$ \\
\hline HGY-1 & 61,10 & 95,50 & 74,63 & II \\
\hline HGY-2 & 51,80 & 98,70 & 94,03 & II \\
\hline HGY-3 & 56,20 & 102,70 & 93,84 & II \\
\hline
\end{tabular}

From the test results of rock mechanical properties, the elastic energy stored in granite could be calculated before reaching the peak value of strength, and the results are shown in Tab. 1. The elastic strain energy of granite was $94,03 \mathrm{~kJ} / \mathrm{m}^{3}$ to $74,63 \mathrm{~kJ} / \mathrm{m}^{3}$ and could be judged as moderate rock burst according to the corresponding criterion.

Tab. 1 showed that the rock burst tendency of granite was in the middle level, and the elastic modulus and compressive strength of the rock samples were relatively high. The samples could absorb considerable strain energy in the loading process. Having strong rock burst tendency, the rock samples were suitable for the analysis of the rock burst problem.

\subsection{Loading mode}

The loading system used in the experiment is the model for the RLW-3000 servo rock mechanics test system. The loading system comprises two parts, including a horizontal loading device and vertical loading device. First, the specimen was loaded in the horizontal direction at $200 \mathrm{kN}$ and in the axial direction at $800 \mathrm{kN}$ with a loading rate of $1,0 \mathrm{kN} / \mathrm{s}$, and this condition was maintained for 5,0 min to form the initial stress field. Second, the roadway excavation was conducted to extract the backfill, and the specimen was maintained for 5,0 min to adjust the stress state. Third, the horizontal load of the specimen was unchanged, and the axial load continued to increase, with loading rates of 0,$30 ; 0,40$ and 0,50 $\mathrm{mm} / \mathrm{min}$, to simulate the stress concentration phenomenon caused by the excavation until $\mathrm{V}$-shaped pits formed on the left and right sides of the holes after many times of rock burst. The loading path is shown in Fig. 2.

\subsection{Experimental methods}

Fractal theory is used to describe more complex irregular geometry attribute terms than the Euclidean geometry space. In a certain range of scales, the fractal structure has no characteristic scale, and the secondary structure is a miniature of the higher structure. In this sense, the fractal presents self-similarity. The test results showed that the macroscopic fracture was the small crack group formed, and the small crack was from a small micro crack evolution of agglomeration. This selfsimilarity of behavior will inevitably lead to fragmentation with a self-similar characteristic. Therefore, using fractal theory to analyze the scale characteristics of rock burst fragments is effective.
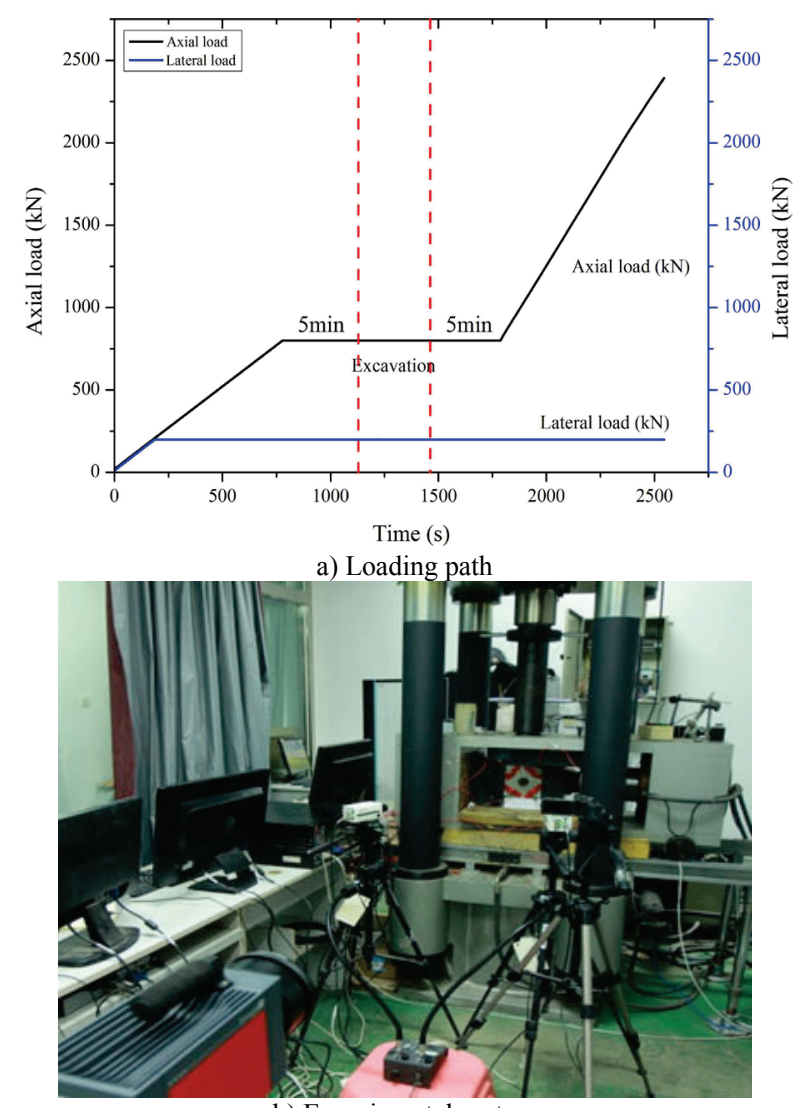

b) Experimental system

Figure 2 Loading path and experimental system

We assumed that the entire fractal $S$ consists of $S_{1}$, $S_{2}, S_{3}, \ldots, S_{n}$ compositions, and $n$ is the nonoverlapping independent partial. If any one of $S_{i}$ enlarge $1 / r_{i}$ times equal to $S\left(0<r_{i}<1, i=1,2,3, \ldots, N\right)$ and $r_{i}=r$, then the formula of fractal dimension $D$ can be expressed as follows [20]:

$D=\ln N / \ln (1 / r)$

The fractal dimension $D$ is derived by using $r$ (the feature size of fragments) and $N$ (the number of fragments more than the size of $r$ ), that is,

$$
N \propto r^{-D}
$$

The distribution function of linear feature size fragments has many forms, and the most representative is 
the Gates-Gaudin-Schumann (G-G-S) distribution. The GG-S empirical model is expressed as follows:

$$
Y=100\left(\frac{X}{X_{m}}\right)^{b} \%,
$$

where $X$ is the distribution parameter. When $X=X_{m}, Y$ is $100 \% . b$ is the rock distribution parameter and is the slope value in double logarithmic coordinates. $M(r)$ is the accumulated dose of fragment mass that is smaller than the feature size $r . M_{S}$ is the total mass of the rock. Then, Eq. (4) becomes:

$$
\frac{M(r)}{M_{S}}=\left(\frac{r}{X_{m}}\right)^{b}
$$

Accordingly,

$$
M=1-\frac{M(r)}{M_{S}}=1-\left(\frac{r}{X_{m}}\right)^{b}
$$

$M$ is the accumulated dose of fragment mass that is larger than the feature size $r$. From Eqs. (2) and (5), the following expressions can be obtained:

$$
\begin{aligned}
& \mathrm{d} N=-D \cdot r^{-D-1} \mathrm{~d} r \\
& \mathrm{~d} M=-\frac{b}{x_{m}^{b}} \cdot r^{b-1} \mathrm{~d} r
\end{aligned}
$$

Considering the relationship between the quantity of rock and the volume of rock, we can derive the following relationship:

$$
\mathrm{d} M \infty r^{3} \mathrm{~d} N
$$

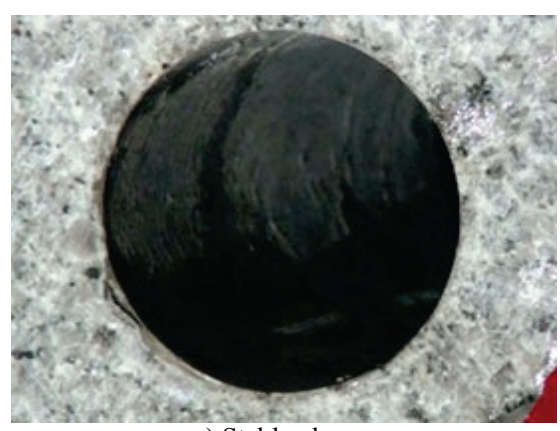

$$
\text { a) Stable phase }
$$

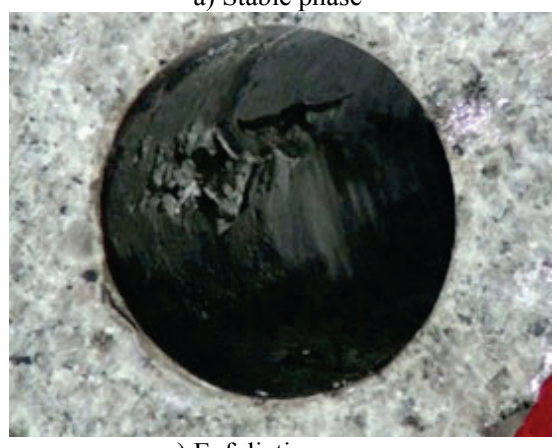

c) Exfoliation
Combining Eqs. (7) and (8), we can obtain the following expression:

$$
r^{-D-1} r^{3} \propto r^{b-1}
$$

Thus, the final formulas used to calculate the relationship between the fractal dimension and the rock mass are as follows:

$$
\begin{aligned}
& b=\frac{\lg \left(M(r) / M_{z}\right)}{\lg r} \\
& D=3-b
\end{aligned}
$$

\section{Result analysis and discussion \\ 3.1 Rock burst test results}

Three experimental schemes rock samples were produced with varying degrees of destructive rock burst, with sudden and violence. In the process of rock burst, the sidewall of the hole has gone through the particle ejection, exfoliation, rock powder spraying etc. The evolution of rock burst is shown in Fig. 3. In the early stage of loading, a quiet period was experienced in the hole of the granite sample. On the surface along the left and right sides of the hole, small particles began to appear and were catapulted out when the axial load reached a certain point. With continued loading, the particle ejection phenomenon initially occurred within the hole and then developed into violent ejection of debris, exfoliation, and a rock avalanche accompanied by the ringing sound of the burst. The rupture position extended from the inner hole to the orifice in the axis direction along the left and right sides. A smoke-like result occurred inside the hole, with a large rock powder spray, and the hole was severely deformed. The experimental results were consistent with four stages, namely, stable phase, particle ejection, exfoliation, and comprehensive collapse.

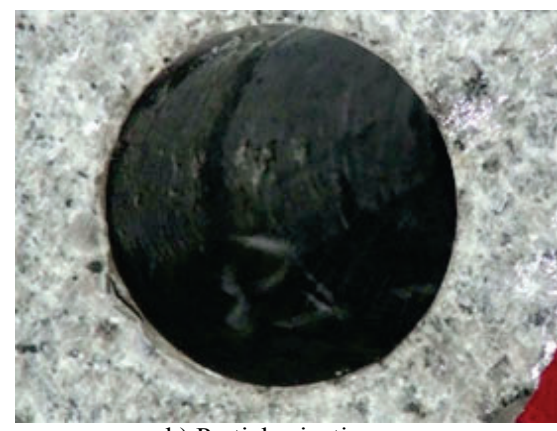

b) Particle ejection

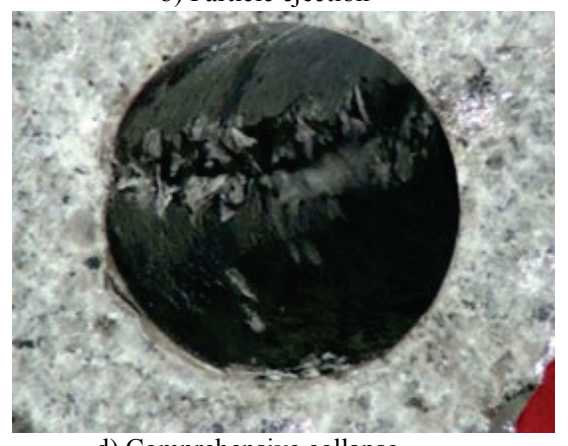

d) Comprehensive collapse

Figure 3 Rock burst stages of granite sample 
Comparisons of the specimens under different loading rates indicated that a large load rate led to violent rock burst. When the loading rate was $0,30 \mathrm{~mm} / \mathrm{min}$, the roadway damage degree was minor. When the loading rate was $0,40 \mathrm{~mm} / \mathrm{min}$, the roadway damage degree was slightly higher, and flaky lithic appeared on both sides of the roadway. Obvious V-shaped burst pits also occurred on both sides of the granite roadway. When the loading rate was $0,50 \mathrm{~mm} / \mathrm{min}$, the roadway damage degree was the highest, with a large number of rock debris avalanches. Among the suspended solids along both sides, as well as the cuttings at the bottom of the roadway, flaky debris occupied the major part. The damage range caused by rock burst was also relatively larger.

Rock, as a viscoelastic body, has sensitivity to time. When the loading rate is increased, the viscous deformation development degree and the plastic deformation become small, which makes the rock show obvious brittle characteristics. Therefore, for granite and other hard brittle rocks, a high loading rate results in heavy rock burst damage.

\subsection{Characteristics of the particle size distribution of rock burst}

From the experimental conditions in this study, the rock burst fragments were divided into four grades, namely, micro, fine, medium, and coarse grains. The clastic rock burst size and classification methods are shown in Tab. 2. The granite debris was classified by using the mass-granularity distribution method and dimension measurement. The results are shown in Fig. 4. The majority of the small amount of thin coarse debris has irregular massive bulk, plate, and column shapes. Small fine particles were mostly in granular form. The granite debris of different sizes also demonstrated a geometric similarity.

Table 2 Rock burst fragment classification and analytical methods

\begin{tabular}{|c|c|c|c|}
\hline Classification & \multicolumn{2}{|c|}{ Particle diameter $(\mathrm{mm})$} & Analytical method \\
\hline Micro grain & \multicolumn{2}{|c|}{$<0,10$} & \multirow{7}{*}{$\begin{array}{c}\text { Mass-granularity } \\
\text { distribution } \\
\text { method }\end{array}$} \\
\hline \multirow{4}{*}{ Fine grain } & \multirow{4}{*}{$0,10 \div 1,25$} & $0,10 \div 0,20$ & \\
\hline & & $0,20 \div 0,46$ & \\
\hline & & $0,46 \div 0,60$ & \\
\hline & & $0,60 \div 1,25$ & \\
\hline Medium grain & \multicolumn{2}{|c|}{$1,25 \div 2,00$} & \\
\hline \multirow[b]{2}{*}{ Coarse grain } & \multirow[b]{2}{*}{$>2,00$} & $2,00 \div 3,00$ & \\
\hline & & $>3,00$ & $\begin{array}{c}\text { Dimension } \\
\text { measurement }\end{array}$ \\
\hline
\end{tabular}
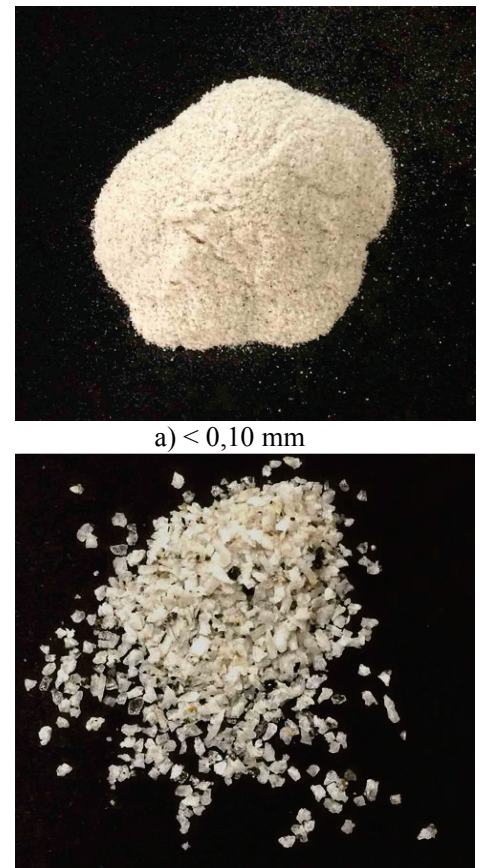

d) $0,46 \div 0,60 \mathrm{~mm}$

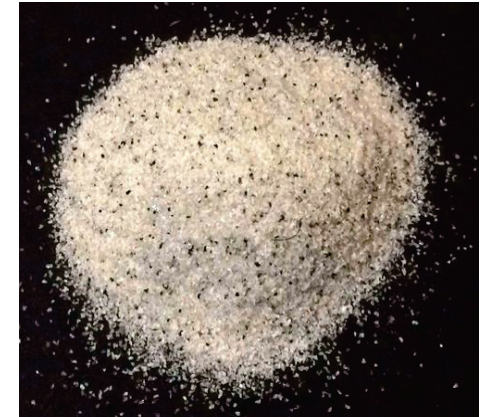

b) $0,10 \div 0,20 \mathrm{~mm}$

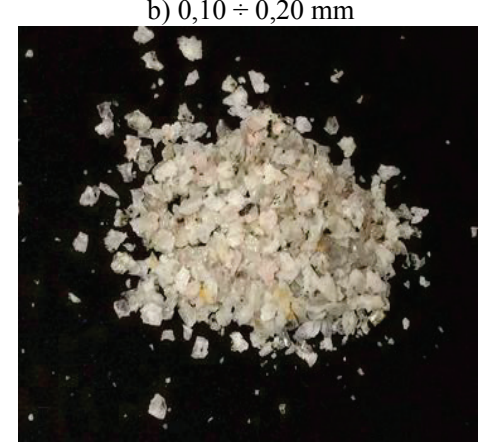

e) $0,60 \div 1,25 \mathrm{~mm}$

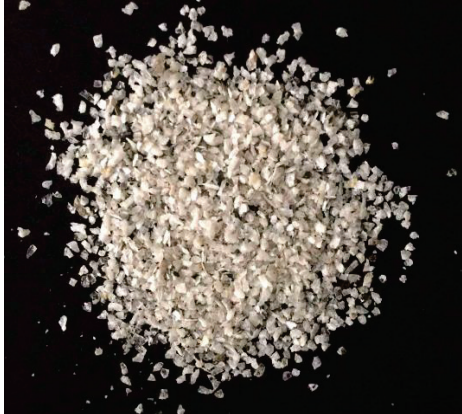

c) $0,20 \div 0,46 \mathrm{~mm}$

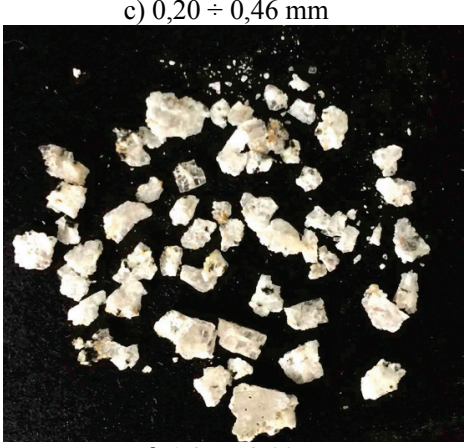

f) $1,25 \div 2,00 \mathrm{~mm}$

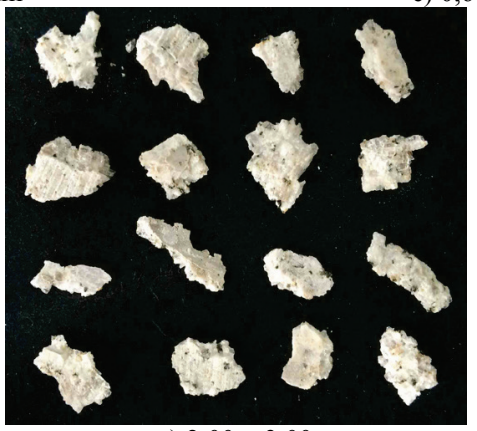

g) $2,00 \div 3,00 \mathrm{~mm}$

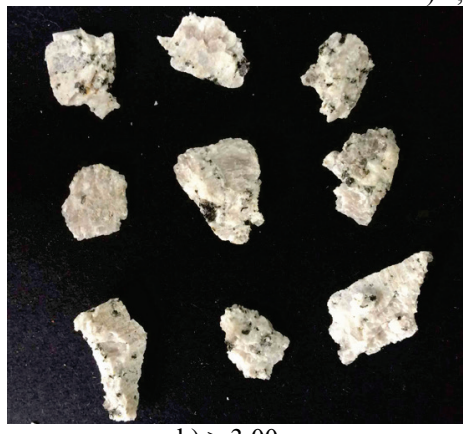

h) $>3,00 \mathrm{~mm}$

Figure 4 Rock fragments of different sizes 
The proportion of the total amount of rock fragments in each experimental condition was obtained by weighing the granite fragments with various sizes under different loading rates, as shown in Tab. 3. The weight of the rock fragments produced by the granite rock burst increased according to the loading rates. Thus, we can conclude that a high loading rate resulted in high damage degrees.

Fig. 5 illustrated that under different loading rates, the percentages of micro grain in granite rock burst were approximately the same. With increasing loading rate, the proportion of fine and medium grains decreased, whereas the proportion of coarse grain increased. Under the condition of low loading rate, substantial energy was required in cutting rock. Under the condition of limited rock burst energy with the rock failure process consuming considerable energy, the kinetic energy was minimal and the damages became small.

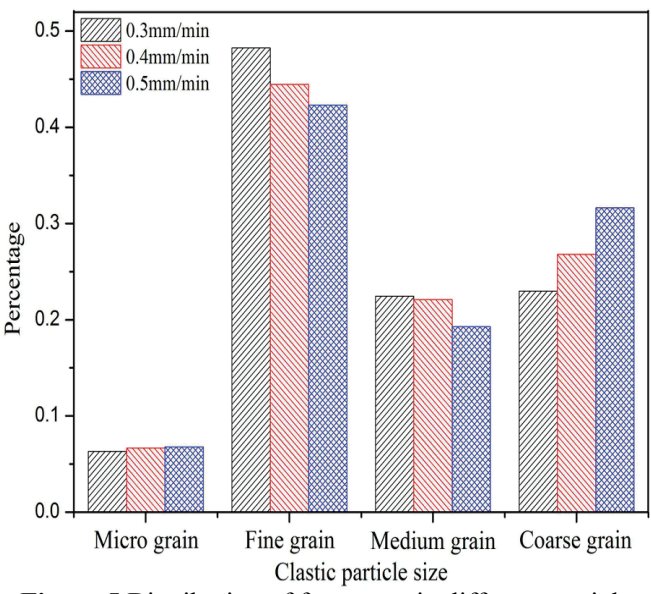

Figure 5 Distribution of fragments in different particles

Table 3 Mass and percentage of different grain groups

\begin{tabular}{|c|c|c|c|c|c|c|}
\hline \multirow{2}{*}{ Grain size grade } & \multicolumn{2}{|c|}{ Loading rate $0,30(\mathrm{~mm} / \mathrm{min})$} & \multicolumn{2}{c|}{ Loading rate $0,40(\mathrm{~mm} / \mathrm{min})$} & \multicolumn{2}{c|}{ Loading rate $0,50(\mathrm{~mm} / \mathrm{min})$} \\
\cline { 2 - 7 } & Mass $(\mathrm{g})$ & Percentage $(\%)$ & Mass $(\mathrm{g})$ & Percentage $(\%)$ & Mass $(\mathrm{g})$ & Percentage $(\%)$ \\
\hline Micro grain & 3,52 & 6,33 & 4,69 & 6,69 & 6,52 & 6,80 \\
\hline Fine grain & 26,83 & 48,25 & 31,16 & 44,44 & 40,55 & 42,29 \\
\hline Medium grain & 12,48 & 22,44 & 15,48 & 22,08 & 18,48 & 19,27 \\
\hline Coarse grain & 12,78 & 22,98 & 18,78 & 26,79 & 30,33 & 31,63 \\
\hline Total & 55,61 & 100 & 70,11 & 100 & 95,88 & 100 \\
\hline
\end{tabular}

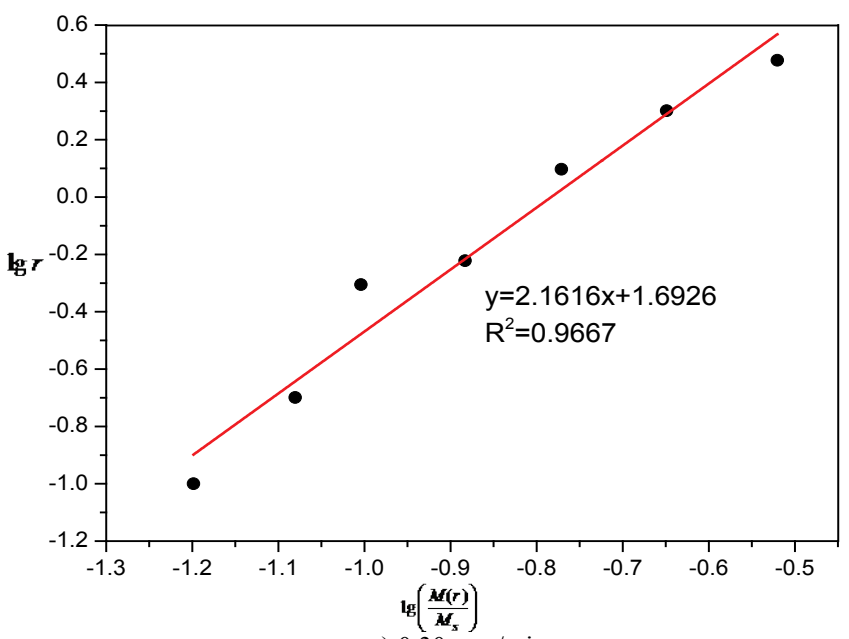

a) $0,30 \mathrm{~mm} / \mathrm{min}$

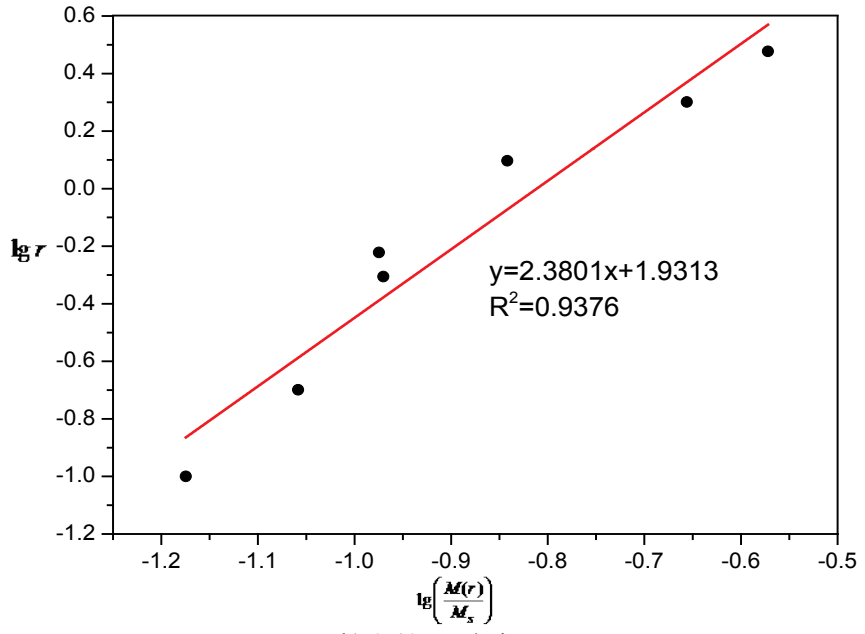

b) $0,40 \mathrm{~mm} / \mathrm{min}$

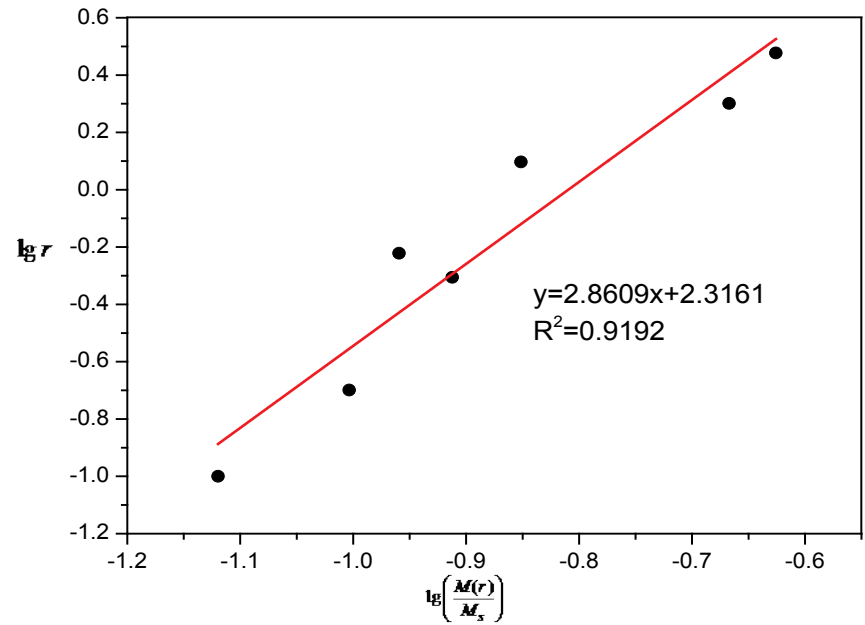

c) $0,50 \mathrm{~mm} / \mathrm{min}$

Figure 6 Fractal dimension calculation results 


\subsection{Fractal features of fragments}

From the calculation method of fractal dimension, the granite fragments could be classified by using the massgranularity distribution method and dimension measurement. The characteristic dimensions of the fractal dimension were determined in the sizes of 0,$10 ; 0,20$; 0,$46 ; 0,60 ; 1,25 ; 2,00$ and $3,00 \mathrm{~mm}$. The calculation results of fractal dimension of rock burst debris under three loading rates are shown in Fig. 6, and the related parameters are presented in Tab. 4.

Table 4 Fractal dimension of the rock burst fragments

\begin{tabular}{|c|c|c|c|c|}
\hline Fractal dimension method & Loading rate $(\mathrm{mm} / \mathrm{min})$ & Relation curve & $R^{2}$ & Fractal dimension $D$ \\
\hline \multirow{2}{*}{$\begin{array}{c}\text { Mass-granularity distribution } \\
\text { method }\end{array}$} & 0,30 & $y=2,1616 x+1,6926$ & 0,9667 & 0,8384 \\
\cline { 2 - 5 } & 0,40 & $y=2,3801 x+1,9313$ & 0,9376 & 0,6199 \\
\cline { 2 - 5 } & 0,50 & $y=2,8609 x+2,3161$ & 0,9192 & 0,1391 \\
\hline
\end{tabular}

\subsection{Fractal analysis}

Fig. 6 and Tab. 4 imply that a high loading rate led to a large slope of the $\lg (M(r) / M)-\lg r$ curve, as well as the fractal dimension reduction. From the seismic data, a seismic time for an event was determined by the distribution of the microseismic event in space of the fractal dimension and energy release. Accordingly, the relationship is expressed in the following formula:

$D=C_{1} \exp \left[-C_{2} E\right]$

where $D$ is the fractal dimension, $C_{1}$ and $C_{2}$ are the constants that vary with region and measurement scales, and $E$ is the energy. The fractal dimension decreased with the increase in the released energy. Therefore, under the condition of high loading rate, the energy release rate of rock burst in the granite roadways was large.

When the loading rate increased, the amount of deformation before rock peak intensity would decrease. The yield phase was short, which was faster than the elastic deformation stage and would cause the yield point to the peak be almost complete in a short time. Therefore, the energy consumption would be small, and the elastic strain energy would be accumulated, which resulted in an increase in both the deformation modulus and strength of the rock. Thus, under low-loading-rate conditions, substantial energy was used for cutting rock, and the accumulated elastic strain energy was small. Under highloading-rate conditions, the strain energy could be released in a short period of time when the rock burst occurred. The result was that the number of fine particles of rock was significantly reduced, and the rock plates were large.

In summary, a high loading rate led to small elastic energy consumption before the collapse of roadways. When a high ratio of elastic strain energy to other energy could be released and the residual energy was small during rock burst, the rocks showed obvious brittle failure. Thus, when the loading rate increased, the released energy of rock burst became large.

\section{Conclusion}

The rock burst tests on granite samples were conducted under different loading rates to analyze the fractal characteristics of the fragments from rock burst. From the particle size characteristics of rock fragments, fractal theory was used to investigate the fractal dimension of rock fragments. The following conclusions are obtained:

(1) The loading rate was proportional to the damage degree of rock burst; with the increase in loading rate, the mass of rock burst fragments increased and the rock burst also became more sudden and sharp, which indicated that a high loading rate led to significant damage caused by rock burst.

(2) The rock burst characteristics of fragments were analyzed under different loading rates by the mass particle size distribution method. The results showed that a high loading rate resulted in small proportions of fine and medium grains and a large proportion of coarse grain, with no significant change in the micro grain.

(3) The results from fractal dimension of the rock burst showed that, under the high-loading-rate condition, the fractal dimension of rock fragments was small and the released energy of rock burst was large.

The distribution law and fractal characteristics of rock debris could explain the mechanism of rock burst to a certain extent. However, the occurrence of rock burst was under the result of multiple factors. So the relationship between the fractal characteristics and the mechanism of rock burst under different conditions should be further investigated in the folloing studies.

\section{Acknowledgement}

This work was supported by National Natural Science Foundation of China (Nos. 51374088, 51574102), Scientific Research Plan Projects for Higher Schools in Hebei Province (Nos. QN2016124), all these are greatly appreciated.

\section{References}

[1] He, M. C.; Sousa, L. R.; Miranda, T.; Zhu, G. L. Rockburst laboratory tests database-Application of data mining techniques. // Engineering Geology. 185, (2015), pp. 116-130. DOI: 10.1016/j.enggeo.2014.12.008

[2] Cook, N. G. W.; Hoek, E.; Pretorius, J. P. G.; Ortlepp, W. D.; Salamon, M. D. G. Rock mechanics applied to the study of rockbursts. // Journal of the South African Institute of Mining and Metallurgy. 66, 10(1966), pp. 435-528.

[3] Cook, N. G. W. The failure of rock. // International Journal of Rock Mechanics and Mining Sciences and Geomechanics Abstracts. 2, 4(1965), pp. 389-403. DOI: 10.1016/0148-9062(65)90004-5

[4] Tang, C. A. Catastrophe of the process of rock fracture. China Coal Industry Publishing House, Beijing, 1993.

[5] He, M. C.; Miao, J. L.; Feng, J. L. Rock burst process of limestone and its acoustic emission characteristics under 
true-triaxial unloading conditions. // International Journal of Rock Mechanics \& Mining Sciences. 47, 2(2010), pp. 286298. DOI: 10.1016/j.jijmms.2009.09.003

[6] Liu, D. Q.; Li, D. J.; Zhao, F.; Wang, C. C. Fragmentation characteristics analysis of sandstone fragments based on impact rockbursttest. // Journal of Rock Mechanics and Geotechnical Engineering. 6, 3(2014), pp. 251-256. DOl: 10.1016/j.jrmge.2014.04.001

[7] Nie, W. Experimental investigation of rockburst behavior of oriented sandstone. Ph.D. Thesis of China University of Mining and Technology, Beijing, Chinese, 2011.

[8] Zhao, F. Experimental study of important influencing factors for strain rockburst. Ph.D. Thesis of China University of Mining and Technology, Beijing, Chinese, 2015.

[9] Xie, H.P.; Liu, J. F.; Ju, Y.; Li, J.; Xie, L. Z. Fractal property of spatial distribution of acoustic emissions during the failure process of bedded rocksalt. // International Journal of Rock Mechanics \& Mining Sciences. $\quad 48, \quad 8(2011)$, pp. 1344-1351. DOI: 10.1016/j.jprmms.2011.09.014

[10] Shivakumar, K.; Rao, M. V. M. S.; Srinivasan, C.; Kusunose, K. Multifractal analysis of the spatial distribution of area rockburst at kolar gold mines. // International Journal of Rock Mechanics and Mining Sciences and Geomechanics Abstracts. 33, 2(1996), pp. 167-172. DOI: 10.1016/0148-9062(95)00066-6

[11] Kruhl, J. H. Fractal-geometry techniques in the quantification of complex rock structures: A special view on scaling regimes, inhomogeneity and anisotropy. // Journal of Structural Geology. 46, (2013), pp. 2-21. DOl: 10.1016/j.jsg.2012.10.002

[12] Nagahama, H. Fractal scalings of rock fragmentation. // Earth Science Frontiers, 7, 1(2000), pp. 169-177.

[13] Huang, Da.; Tan, Q.; Huang, R. Q. Fractal characteristics of fragmentation and correlation with energy of marble under unloading with high confining pressure. // Chinese Journal of Rock Mechanics and Engineering. 31, 7(2012), pp. 1379-1389.

[14] Hogan, J. D.; Rogers, R. J.; Spray, J. G. Suporn Boonsue. Dynamic fragmentation of granite for impact energies of 628 J. // Engineering Fracture Mechanics. 79, (2012): 103125. DOI: 10.1016/j.engfracmech.2011.10.006

[15] Feng, X. T.; Yu, Y.; Feng, G. L.; Xiao, Y. X.; Chen, B. R.; Jiang, Q. Fractal behaviour of the microseismic energy associated with immediate rockbursts in deep, hard rocktunnels. // Tunnelling and Underground Space Technology. 51, (2016), pp. 98-107. DOI: 10.1016/j.tust.2015.10.002

[16] He, M. C.; Nie, W.; Han, L. Q.; Ling, L. J. Microcrack analysis of Sanya granite fragments from rockburst tests. // Mining Science and Technology. 20, 2(2010), pp. 238-243.

[17] Li, D.; Zhao, F.; Zheng, M. Fractal characteristics of cracks and fragments generated in unloading rockburst tests. // International Journal of Mining Science \& Technology. 24, 6(2014), pp. 819-823. DOl: 10.1016/j.jmst.2014.10.014

[18] Sujatha, V.; Kishen, J. Energy release rate due to friction at biomaterial interface in dams. // Journal of Engineering Mechanics, 129, 7 (2003), pp. 793-800. DOI: 10.1061/(ASCE)0733-9399(2003)129:7(793)

[19] Song, D. Z.; Wang, E. Y.; Li, Z. H.; Liu, J.; Xu, W. Q. Energy dissipation of coal and rock during damage and failure process based on EMR. // International Journal of Mining Science \& Technology. 25, 5(2015), pp. 787-795. DOI: 10.1016/j.jimst.2015.07.014

[20] Li, T. J.; Wang, Y. H.; Zhang, M. Y.; Li, Q. G.; Xu, Y.; Tan, G. H. Fractal properties of crack in rock and mechanism of rockburst. // Chinese Journal of Rock Mechanics \& Engineering. 19, 1(2000), pp. 6-10.

\section{Authors' addresses}

Bao-zhu Tian, PhD Candidate (Corresponding author)

1) College of Resources and Civil Engineering, Northeastern University, No. 3-11, Wenhua Road, Shenyang, 110819, P. R. China

2) North China University of Science and Technology, Tangshan, 063000, P. R. China

E-mail: 562535624@qq.com

\section{Shan-jun Liu, PhD, Professor}

College of Resources and Civil Engineering, Northeastern University, No. 3-11, Wenhua Road, Shenyang, 110819, P. R. China

E-mail: liusjdr@126.com

Yan-bo Zhang, PhD, Professor

North China University of Science and Technology, 46 Xinhua Road, Tangshan, 063009, P. R. China E-mail: fzdn4444@126.com

Zhan-le Wang, PhD

Electronic Systems Engineering, University of Regina, Regina S4S0A2, Canada

E-mail: 16525521@qq.com 